\title{
Long-term Outcome after Inflammatory Abdominal Aortic Aneurysm Repair: Case-matched Study
}

\author{
Luigi Bonati, M.D., ${ }^{1}$ Patrizia Rubini, M.D., Ph.D., ${ }^{1}$ Gioacchino G. Japichino, M.D., ${ }^{1}$ Alessandro Parolari, M.D., Ph.D., ${ }^{2}$ \\ Sandro Contini, M.D., ${ }^{1}$ Roberto Zinicola, M.D., ${ }^{1}$ Melissa Fusari, M.D., ${ }^{2}$ Paolo Biglioli, M.D. ${ }^{2}$ \\ ${ }^{1}$ Institute of General Surgery and Organ Transplantation, University of Parma, Via Gramsci 14, 43100 Parma, Italy \\ ${ }^{2}$ Department of Cardiac Surgery, Centro Cardiologico Monzino, Istituto di Ricovero e Cura a Carattere Scientifico (IRCCS), University of Milan, Via \\ Parea 4, 20138 Milano, Italy
}

\begin{abstract}
The purpose of this study was to compare early and late outcomes after inflammatory and noninflammatory abdominal aortic aneurysm (AAA) repair with emphasis on graft-related complications. Of 625 consecutive patients submitted to AAA repair, 18 were classified as having inflammatory AAAs (group 1). The results of this group were compared with those of 54 patients (group 2) retrospectively drawn from patients who underwent aortic replacement for noninflammatory AAAs. A computerassisted matching system was used to match patients according to date of birth, gender, and surgical priority. All patients of both groups were followed by periodic clinical and instrumental examinations. Patients in group 1 complained more frequently of aneurysm-related symptoms $\mathbf{( 7 2 \%}$ vs. $20 \% ; p=0.0001$ ), and their erythrocyte sedimentation rate was elevated more often $(78 \%$ vs. $19 \% ; p<0.0001)$. Surgical morbidity and mortality rates were not different. The mean lengths of follow-up were $61 \pm 47$ months (group 1) and $71 \pm 38$ months (group 2). The 10-year overall survival rates did not differ significantly between the two groups $(49.1 \% \pm$ $16.9 \%$ for group $1 \mathrm{vs.} 61.6 \% \pm 13.8 \%$ for group $2 ; p=0.26$, log-rank test). In contrast, the free from paraanastomotic aneurysm survival rates were significantly lower in group $1(57.3 \% \pm 20.2 \%$ vs. $97.8 \% \pm 2.5 \%$ at 10 years; $p$ $=0.025$, log-rank test). Long-term outcomes showed a higher incidence of graft-related complications in group 1. As inflammatory aneurysms might represent a risk factor for the development of paraanastomotic aneurysms, routine imaging surveillance of graft aortic healing after inflammatory AAA repair is warranted.
\end{abstract}

Inflammatory (noninfectious) abdominal aortic aneurysms (AAAs) [1] are characterized by marked thickness of the aortic wall, with dense perianeurysmal fibrosis involving adjacent organs. [2] It is not certain whether they have an independent pathogenesis or simply represent the extreme end in the spectrum of inflammatory changes present in all AAAs and even in atherosclerotic plaques [2-5]. Nevertheless, they may be considered a distinct clinical entity because of their histologic features and associated surgical problems [2, 6-9]. Almost all reports concerning late outcomes after inflammatory AAA repair have focused on the evolution of perianeurysmal fibrosis [10-13]. Imaging follow-up studies of graft-

This paper is dedicated to the memory of Prof. Giancarlo Botta, M.D. Correspondence to: Patrizia Rubini, M.D., Ph.D. related complications in comparison with those of noninflammatory AAAs have rarely been reported [14-16]. Some experiences using a clinical follow-up examination showed no significant differences in long-term survival rates between inflammatory and noninflammatory AAAs $[6,7,16,17]$.

This study is a case-control analysis of early and late outcomes of 18 patients who underwent repair of an inflammatory AAA during the period January 1987 to December 1999. We included 54 control patients operated on for noninflammatory aneurysms during the same period, matched for gender, age, and surgical priority.

\section{Patients and Methods}

Patients

From January 1987 to December 1999 a total of 625 consecutive patients underwent AAA repair. AAAs were defined as being inflammatory when macroscopic and microscopic findings were observed as follows: (1) tomographic or intraoperative gross appearance of marked thickening of the aneurysm wall with encasement of surrounding retroperitoneal organs; and (2) adventitial fibrosis together with inflammatory infiltrates of lymphocytes and plasma cells, endarteritis obliterans, and fibrosis around nerves, as previously described in the literature $[2,3,18]$. Based on these criteria, $18(2.8 \%)$ patients were considered to have an inflammatory AAA (group 1). A control group (group 2) with noninflammatory AAAs was retrospectively drawn from the remaining 607 patients who underwent abdominal aortic replacement during the same period. For each patient in group 1, three control patients were identified using a computer-assisted matching system to match patients according to date of birth, gender, and surgical priority (elective surgery vs. emergent surgery).

Preoperative clinical features and cardiovascular risk factors were compared in the two groups, and operative reports were reviewed to identify differences in the surgical technique and associated procedures. Postoperative (within 30 days after surgery) mortality and morbidity, late survival rates, and graft-related complications were compared. 


\section{Surgical Procedure}

A transperitoneal approach was used in all cases. In group 1 aortic replacement was performed avoiding extensive dissections and by the in-lay graft technique, according to Crawford et al. [6]. Dacron polyester (woven or knitted) and polypropylene sutures were used in all patients. A specimen of the aneurysmal aortic wall was routinely removed and sent for histopathologic evaluation in all cases. Aneurysm repair was accomplished by experienced vascular surgeons certified in general and vascular surgery. Steroids were not administered before or after operation.

\section{Follow-up}

Follow-up was routinely performed 6 months after operation by clinical examination and laboratory tests and yearly by computed tomography (CT) scanning. The last inquiry was made between January 2000 and December 2000. The differentiation between true and false aneurysms was performed on the basis of criteria defined by Johnston et al. [1].

\section{Statistical Analysis}

All continuous data are expressed as means $\pm \mathrm{SD}$, and categorical variables are reported as a percent. Commercial statistical software (SPSS for Windows, version 8.0; SPSS, Chicago, IL, USA) has been used for data analysis. Continuous data were compared by one-way analysis of variance (ANOVA) and categorical data by the chisquare test or Fisher's exact test when indicated. Total survival and "free from anastomotic pseudoaneurysm development" survival rates of both patient populations were determined by KaplanMeier survival analysis; the estimated survival proportions are reported \pm standard error of the estimates. Differences in survival and "free from anastomotic pseudoaneurysm development" survival were compared by the log-rank test. A $p$ value less than 0.05 was considered significant.

\section{Results}

\section{Preoperative Risk Factors and Clinical Presentation}

As expected from the selection criteria for the control group, the two groups were similarly matched for age, gender, and surgical priority. Differences between the groups were found regarding clinical presentation and signs but not for preoperative risk factors (Table 1). The incidence of symptoms was in fact significantly higher in group 1 patients, who also had an elevated erythrocyte sedimentation rate (ESR) more often. Abdominal and back pain were the most common presenting symptoms in group 1 (11 cases, $65 \%$ ); however, of these 11 patients, only 1 had a true rupture of the aneurysm. Two more patients in group 1 were admitted to hospital for symptoms referable to obstructive uropathy.

\section{Operative Features}

Inflammatory AAAs showed a typical white surface and dense perianeurysmal fibrosis that entrapped the duodenum in all cases $(100 \%)$, the inferior vena cava and left renal vein in $10(55.5 \%)$ and $8(44.4 \%)$ cases, respectively, the ureters with varying degrees of obstruction in $6(33.3 \%)$, and the small bowel in 1 case $(5.5 \%)$.
Table 1. Preoperative risk factors and clinical presentation.

\begin{tabular}{lccc}
\hline Variable & $\begin{array}{c}\text { Group 1 } \\
\text { patients } \\
(n=18)\end{array}$ & $\begin{array}{l}\text { Group 2 } \\
\text { patients } \\
(n=54)\end{array}$ & \multicolumn{1}{c}{$p$} \\
\hline Male gender & $18(100 \%)$ & $54(100 \%)$ & 1.00 \\
Age at intervention & $67.0 \pm 8.7$ & $67.0 \pm 9.4$ & 1.00 \\
Smokers & $12(66.6 \%)$ & $37(68.5 \%)$ & 1.00 \\
Chronic obstructive pulmonary & $4(22.2 \%)$ & $22(40.7 \%)$ & 0.26 \\
$\quad$ disease & $1(5.5 \%)$ & $4(7.4 \%)$ & 1.00 \\
Familiar history of aneurysms & $4(22.2 \%)$ & $23(42.5 \%)$ & 0.16 \\
Coronary artery disease & $5(27.7 \%)$ & $7(12.9 \%)$ & 0.16 \\
$\begin{array}{l}\text { Serum creatinine increase } \\
\quad( \pm 2 \text { mg/dl) }\end{array}$ & $8(44.4 \%)$ & $29(53.7 \%)$ & 0.50 \\
Hypertension & $3(16.7 \%)$ & $8(14.8 \%)$ & 1.00 \\
$\begin{array}{l}\text { Diabetes } \\
\text { Hyperlipidemia }\end{array}$ & $7(38.8 \%)$ & $31(57.4 \%)$ & 0.18 \\
$\begin{array}{l}\text { Peripheral arterial occlusive } \\
\quad \text { disease }\end{array}$ & $4(22.2 \%)$ & $20(37.0 \%)$ & 0.39 \\
$\begin{array}{l}\text { Symptomatic AAAs } \\
\text { ESR elevation }\end{array}$ & $13(72.2 \%)$ & $11(20.4 \%)$ & 0.0001 \\
Emergent operation & $14(77.7 \%)$ & $10(18.5 \%)$ & $<0.0001$ \\
\hline
\end{tabular}
rysms.

ESR: erythrocyte sedimentation rate; AAAs: abdominal aortic aneu-

Treatment of ureteral involvement depended on the degree of ureteral obstruction: Ureteral stenting and ureterolysis were performed in two patients with severe bilateral obstruction, and the remaining patients underwent aneurysm resection alone. None of the noninflammatory AAAs had adjacent retroperitoneal organ adhesion. Intraoperative factors-such as the site of clamping (below or above renal arteries), type of graft replacement (straight or bifurcated graft), incidence of left renal vein division, or associated vascular and nonvascular procedures-were not different between the two groups (Table 2).

\section{Postoperative Outcomes}

There were no perioperative deaths. In-hospital morbidity rates and the various complications are shown in Table 3. No significant differences were found between inflammatory and noninflammatory AAAs.

\section{Long-term Outcomes}

The mean follow-up was $61 \pm 47$ months for group 1 and $71 \pm 38$ months for group $2(p=0.78)$. Cumulative survival rates (Fig. 1) were lower, although not significantly so, for group 1 than for group $2(49.1 \% \pm 16.9 \%$ vs. $61.6 \% \pm 13.8 \%$ at 10 years; $p=0.26)$; conversely, "free from paraanastomotic aneurysm" survival rates (Fig. 2) were significantly lower in group $1(57.3 \% \pm 20.2 \%$ vs. $97.8 \% \pm$ $2.5 \%$ at 10 years; $p=0.025$ ).

In detail, paraanastomotic aneurysms in group 1 occurred at the aortic proximal anastomosis (two cases) and at the iliac anastomosis (one case); the only complication of this type in group 2 occurred at a femoral anastomosis. The first proximal paraanastomotic aneurysm of group 1 was detected 50 months after primary aortic repair in a patient who had undergone ileal resection for volvulus on postoperative day (POD) 8 ; it measured $5.4 \mathrm{~cm}$ in diameter. Surgical treatment was required 1 year later because of its enlargement. At surgery a true aneurysm was seen to involve the aorta adjacent to the suture line. Repair was accomplished by suprarenal cross- 
Table 2. Operative details and associated surgery.

\begin{tabular}{lccc}
\hline Variable & $\begin{array}{l}\text { Group 1 } \\
\text { patients } \\
(n=18)\end{array}$ & $\begin{array}{l}\text { Group 2 } \\
\text { patients } \\
(n=54)\end{array}$ & $p$ \\
\hline Operative details & $7(38.8 \%)$ & $15(27.7 \%)$ & 0.38 \\
$\quad$ Straight graft & $19 \pm 3$ & $19 \pm 2$ & 0.73 \\
Graft diameter (mm) & $2(11.1 \%)$ & $3(5.5 \%)$ & 0.59 \\
Left renal vein division & $15(83.3 \%)$ & $47(87.0 \%)$ & 0.70 \\
Infrarenal clamping & & & \\
Associated surgery & $5(27.7 \%)$ & $9(16.6 \%)$ & 0.32 \\
Vascular surgery & $3(16.6 \%)$ & $4(7.4 \%)$ & \\
Lumbar sympathectomy & - & $2(3.7 \%)$ & \\
Renal artery angioplasty & $2(11.1 \%)$ & $1(1.8 \%)$ & \\
Lower limb revascularization & - & $2(3.7 \%)$ & \\
$\quad$ Carotid endarterectomy & $4(22.2 \%)$ & $21(38.8 \%)$ & 0.26 \\
Nonvascular surgery & $1(5.5 \%)$ & $6(11.1 \%)$ & \\
Cholecystectomy & - & $3(5.5 \%)$ & \\
$\quad$ Nephrectomy & - & $1(1.8 \%)$ & \\
Splenectomy & - & $3(5.5 \%)$ & \\
Hiatal hernia repair & $3(16.6 \%)$ & $8(14.8 \%)$ & \\
$\quad$ Inguinal hernia repair & & & \\
\hline
\end{tabular}

Table 3. Postoperative outcome.

\begin{tabular}{lccc}
\hline & $\begin{array}{c}\text { Group 1 } \\
\text { patients } \\
(n=18)\end{array}$ & $\begin{array}{l}\text { Group 2 } \\
\text { patients } \\
(n=54)\end{array}$ & $p$ \\
Variable & $6(33.3 \%)$ & $22(40.7 \%)$ & 0.78 \\
\hline Cardiac & $4(22.2 \%)$ & $11(20.3 \%)$ & \\
Arrhythmias & $1(5.5 \%)$ & $7(12.9 \%)$ & \\
Ischemia & $1(5.5 \%)$ & $4(7.4 \%)$ & \\
Congestive heart failure & $1(5.5 \%)$ & $3(5.5 \%)$ & 1.00 \\
Pulmonary & $1(5.5 \%)$ & $1(1.8 \%)$ & \\
Prolonged ventilation (> 48 hours) & - & $2(3.7 \%)$ & \\
Pneumonia/severe atelectasis & $2(11.1 \%)$ & $4(7.4 \%)$ & 0.64 \\
Vascular & $2(11.1 \%)$ & $1(1.8 \%)$ & \\
Acute lower limb ischemia & - & $1(1.8 \%)$ & \\
Deep vein thrombosis & - & $2(3.7 \%)$ & \\
Groin lymphatic leak & $5(27.7 \%)$ & $12(22.2 \%)$ & 0.75 \\
Renal & $3(16.6 \%)$ & $5(9.2 \%)$ & \\
Serum creatinine rise & $2(11.1 \%)$ & $7(12.9 \%)$ & \\
Urinary tract infections & $3(16.6 \%)$ & $3(5.5 \%)$ & 0.16 \\
Intestinal & $2(11.1 \%)$ & $1(1.8 \%)$ & \\
Occlusion & $1(5.5 \%)$ & $1(1.8 \%)$ & \\
Prolonged paralytic ileus & - & $1(1.8 \%)$ & \\
Ischemia & - & $3(5.5 \%)$ & 0.57 \\
Other & $8(44.4 \%)$ & $22(40.7 \%)$ & 1.00 \\
Overall morbidity ${ }^{a}$ & 0 & 0 & 1.00 \\
Mortality & & &
\end{tabular}

${ }^{a}$ Some patients had more than one complication; for that reason the sum of the complication rates in both groups does not give the exact rate of overall morbidity.

clamping and by placing a graft proximal to the old one. The patient was discharged without complications, but 3 years later he developed a prosthetic-duodenal fistula, which was treated by duodenal resection and aortic replacement with a cryopreserved homograft. The patient died from a homograft rupture on POD 7. The second patient with an aortic paraanastomotic aneurysm underwent emergency operation because of rupture 70 months after the primary repair; the rupture occurred at a focal bulging of the aortic wall at the anastomotic site. Prosthetic replacement of the old graft was carried out, but the patient died on POD 4 from multiple organ failure. The third anastomotic aneurysm, located at an iliac anastomosis, was discovered 88 months after the primary operation; it measured $4.4 \mathrm{~cm}$ in diameter and was treated successfully by endo-
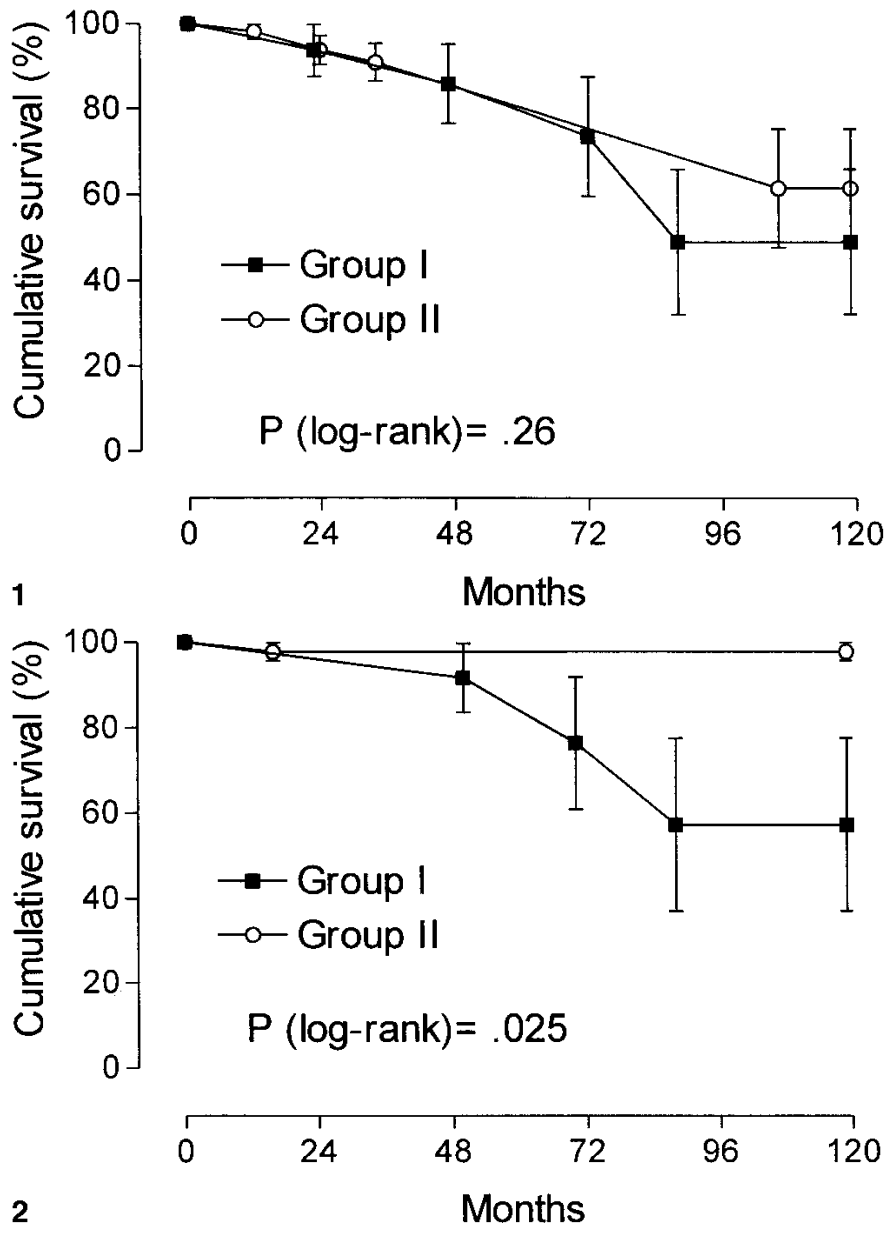

Fig. 1. Time-related survival after abdominal aortic aneurysm (AAA) replacement in group 1 and 2 patients. Note the lack of significance between groups $(p=0.26)$.

Fig. 2. Time-related "free from paraanastomotic aneurysm" survival after AAA replacement in group 1 and 2 patients. There is a statistically significant difference in survival $(p=0.025)$.

Table 4. Late outcome.

\begin{tabular}{lcll}
\hline Variable & $\begin{array}{c}\text { Group 1 } \\
\text { patients } \\
(n=18)\end{array}$ & $\begin{array}{l}\text { Group 2 } \\
\text { patients } \\
(n=54)\end{array}$ & $p$ \\
\hline Follow-up length (months) & $61 \pm 47$ & $71 \pm 38$ & 0.78 \\
Graft-unrelated complications & 7 & 13 & \\
Cardiac & 5 & 7 & \\
Neoplastic & - & 2 & \\
Cerebrovascular & 1 & 4 & \\
Gastrointestinal & 1 & - & \\
Graft-related complications & 3 & 1 & \\
Aortic pseudoaneurysms & 2 & - & \\
Iliac pseudoaneurysms & 1 & - & \\
Femoral pseudoaneurysms & - & 1 & \\
Graft-related mortality & 2 & - & \\
Aortic pseudoaneurysm rupture & 1 & - & \\
Aortic homograft rupture & 1 & - & \\
Graft-unrelated mortality & 3 & 7 & \\
Cardiac & 2 & - & \\
Cerebrovascular & 1 & 1 & \\
Trauma & - & & \\
$\quad$ Neoplastic & - & &
\end{tabular}


Table 5. Late outcome: literature review.

\begin{tabular}{|c|c|c|c|c|c|c|c|}
\hline \multirow[b]{2}{*}{ Study } & \multirow[b]{2}{*}{$\begin{array}{l}\text { No. of patients } \\
\text { followed }\end{array}$} & \multirow[b]{2}{*}{ Methods of detection } & \multirow[b]{2}{*}{$\begin{array}{l}\text { Graft-related } \\
\text { complications }(\%)\end{array}$} & \multicolumn{3}{|c|}{ No. of patients } & \multirow[b]{2}{*}{$\begin{array}{l}\text { Follow-up length } \\
\text { (months) }\end{array}$} \\
\hline & & & & Infection & $\begin{array}{l}\text { Aortoenteric } \\
\text { fistula }\end{array}$ & $\begin{array}{l}\text { Paraanastomotic } \\
\text { aneurysms }\end{array}$ & \\
\hline Lindblad [10] & 35 & CT, US, urography & $8.5 \%$ & 2 & 1 & - & $12-96$ \\
\hline Nitecki [15] & 19 & CT, US & $5.2 \%$ & 1 & - & - & $12.9 \pm 1.7($ mean $)$ \\
\hline Koch [14] & 54 & $\mathrm{CT}$ & $9.2 \%$ & - & 1 & 4 & 30 (mean) \\
\hline Von Fritschen [12] & 26 & $\mathrm{CT}$ & - & - & - & - & 36 (median) (10-91) \\
\hline
\end{tabular}

CT: computed tomography; US: ultrasonography.

vascular stenting. In group 2 a patient with a femoral pseudoaneurysm, detected 16 months after the primary operation, electively underwent iliac-femoral graft replacement. Graft infection was not found in cultures of any of the replaced grafts. The late complications of both groups are shown in Table 4 .

\section{Evolution of Fibrosis in Group 1 Patients}

Symptoms and elevated ESRs disappeared within 12 to 18 months after aneurysm repair. Hydronephrosis regressed within the same period in patients treated by ureterolysis as well as in those who underwent aneurysm repair alone; neither recurrence nor progression of ureteral obstruction was detected. CT scanning follow-up showed complete regression of retroperitoneal fibrosis in 11 patients $(61.1 \%)$ and partial regression in $7(38.8 \%)$ at an average follow-up of $61 \pm 47$ months.

\section{Discussion}

Imaging follow-up studies evaluating aortic-graft healing after aneurysm repair are infrequent in the literature. Therefore the true rate of false aneurysm development is still undefined not only for inflammatory AAAs but also after noninflammatory AAA repair. The wide range of rates previously reported is probably due to the various procedures, prosthetic materials, length of follow-up, and methods of detection as well as the aggressiveness with which these lesions have been sought [19-22]. Edwards et al. followed up with yearly sonographic examination 111 patients who underwent aortic bypass grafting for AAA or occlusive disease; they documented a paraanastomotic aneurysm rate of $27 \%$ at 15 years [23]. Hallett et al., in a population-based study, evaluated graft-related complications after AAA repair by ultrasonography, CT scanning, or both. They reported that $3 \%$ of patients showed anastomotic aneurysms (1\% at the aortic anastomosis) at a median follow-up of 6.1 years [24]. More recently, Kalman et al. performed CT scan follow-up 8 to 9 years postoperatively in a cohort of patients enrolled in the Canadian Aneurysm Group and documented a $7.5 \%$ rate of proximal false aneurysms [25].

Late surveillance of aortic graft healing after inflammatory AAA repair using routine CT scans or sonographic follow-up examinations has been reported even more rarely. Nitecki et al., in a casecontrol study using CT or ultrasound scans for follow-up, reported similar 5-year survival rates for inflammatory and noninflammatory AAAs, without any occurrence of pseudoaneurysms in inflammatory AAAs [15]. A review of the literature concerning graftrelated complications after inflammatory AAA repair is reported in Table $5[10,12,14,15]$.

Our single-institution case-matched study showed that inflam- matory AAA repair is associated with a higher incidence of anastomotic aneurysms than noninflammatory AAA repair despite early outcomes and late cumulative survival rates that were not significantly different. It should be noted that the number of patients in this study is fairly small because of the strict criteria adopted to define the inflammatory AAA; our prevalence is in fact relatively low $(2.8 \%)$ compared with other previously reported experiences $[2,3,7,8,17]$. However, the selection procedure allowed us to obtain two groups with similar preoperative risk factors followed by periodic instrumental examination and to make the groups strictly comparable.

Patients with symptoms due to the aneurysm and ESR elevation were found more frequently among those with inflammatory AAAs according to data reported in most surgical series $[6-8,10,15-17$, 26]. Nevertheless, different preoperative results have been described in other studies. Similar incidences of symptomatic patients regarding inflammatory and noninflammatory AAAs have been reported by Johnston and Scobie in a multicenter study of 666 patients with nonruptured AAAs [27]; iatrogenic lesions in surrounding organs and increased postoperative complications in inflammatory AAA patients have been noted by others [7-9, 15, 27-29].

Late evolution of periaortic fibrosis in inflammatory AAAs is still controversial. Some reports showed regression after graft repair in almost all patients, $[6,7,10,17,26]$, whereas more recent studies have shown partial or no regression of the fibrotic process [11-13, 15]. Certainly, the length and the methods of follow-up vary among papers, and some observations are sporadic. A literature review revealed that complete fibrosis regression was noted in $23 \%$ to $53 \%$ of cases, partial regression in $21 \%$ to $57 \%$, and no change or progression of inflammation in 0 to $38 \%$ and 0 to $3.8 \%$, respectively [11-13, 15]. The overall mean follow-up in these reports is about 2 years. In our study, most patients showed regression of the fibrotic process after about 5 years. Thus it can be hypothesized that regression of fibrosis can take several years to complete, and that such a process is not necessarily related to normalization of the ESR, which occurs much earlier during the follow-up of these patients.

The higher incidence of paraanastomotic aneurysms after inflammatory AAA repair in our study raises the question of whether they have specific features predisposing to the development of this complication. Histopathologic changes of the aortic wall could play a pathogenetic role in the development of these complications. Flogistic infiltrates and endarteritis obliterans with subsequent ischemic aortic wall damage could induce arterial weakness leading to pseudoaneurysmal degeneration. Recent studies investigating the extracellular matrix modifications by immunoelectron microscopy and immunohistochemical techniques have shown that elastin depletion and collagen fiber alterations are more extensive in in- 
flammatory AAAs than in noninflammatory AAAs [30]. It is likely that these or other unidentified defects affect the resistance of the aortic wall, predisposing to late anastomotic aneurysm development.

\section{Conclusions}

Our study suggests that inflammatory AAAs constitute a risk factor for late paraanastomotic aneurysm development. Large series with imaging follow-up are warranted to detect the true incidence of late graft pathology in this type of aneurysm and to confirm the tendency for anastomotic aneurysms to develop more frequently with inflammatory AAAs than with noninflammatory AAAs.

Résumé. Le but de cette étude a été de comparer l'évolution précoce et tardive de la cure d'anévrisme de l'aorte abdominale (AAA), en distinguant entre les AAA inflammatoire et non-inflammatoire et en insistant sur les complications en rapport avec le greffon. De 625 patients consécutifs ayant eu une cure de leur AAA, 18 ont été classés comme inflammatoires (groupe 1). Les résultats de ce groupe ont été comparés à ceux de 54 patients (groupe 2), tirés rétrospectivement parmi les patients qui ont eu un remplacement de l'aorte pour AAA non inflammatoire. Un système d'appariement assisté par ordinateur a été utilisé pour apparier les patients selon la date de naissance, le sexe et le degré d'urgence de la chirurgie. Tous les patients ont été suivis par un examen périodique clinique et paraclinique. Les patients du groupe 1 se sont plaints plus souvent de symptômes en rapport avec l'anévrysme (72\% vs. $20 \%, p=$ 0.0001) et avaient une vitesse de sédimentation plus élevée (78\% vs. $19 \%, p$ $<0.0001$ ). La morbidité et mortalité chirurgicales n'étaient pas différentes. Le suivi moyen a été de $61 \pm 47$ mois dans le groupe 1 et de 71 $\pm \mathbf{3 8}$ mois dans le groupe 2 . La survie à 10 ans ne différait pas de façon significative entre les deux groupes $(49.1 \% \pm 16.9 \%$ pour le groupe 1 vs. $61.6 \% \pm 13.8 \%$ pour le groupe $2, p=0.26$, test du log-rank) alors que la survie sans anévrysme para-anastomotique a été significativement moins élevée dans le groupe $1(57.3 \% \pm 20.2 \%$ vs. $97.8 \% \pm 2.5 \%$ à 10 ans, $p=$ 0.025 , test de log-rank). L'évolution à long terme a montré une incidence plus élevée de complications en rapport avec le greffon dans le groupe 1. Comme l'inflammation pourrait représenter un facteur de risque pour le développement de faux anévrysmes para-anastomotique, on conseille une surveillance régulière de la cicatrisation après cure d'AAA inflammatoire.

Resumen. El objetivo del trabajo fue comparar los resultados precoces y tardíos del tratamiento quirúrgico de aneurismas de la aorta abdominal (AAAs) de etiología inflamatoria. En el estudio se enfatiza sobre las complicaciones relacionadas con el injerto. De 625 pacientes tratados por AAA, 18 fueron clasificados en el grupo AAA inflamatorio (grupo 1) comparándose con 54 pacientes (grupo 2) elegidos retrospectivamente por padecer un AAA no inflamatorio. Mediante un sistema computerizado se conformaron grupos homologables por lo que a la fecha de nacimiento, sexo y urgencia quirúrgica se refiere. Los pacientes del grupo 1 presentaban con más frecuencia síntomas relacionados con el aneurisma (72\% vs. $20 \% p=0.0001)$. La velocidad de sedimentación también estaba más elevada $(78 \%$ vs. $19 \% p<0.0001)$. Sin embargo, las tasas de morbi-mortalidad no fueron diferentes. El seguimiento medio fue de $61 \pm$ 47 (grupo 1) y $71 \pm 38$ meses (grupo 2). La supervivencia global a los 10 años fue similar $(49.1 \pm 16.9 \%$ grupo 1 y $61.6 \% \pm 13.8 \%$ grupo 2 ; log rank test $p=0.26$ ). Sin embargo, el porcentaje de supervivencia sin aneurismas para-anastomóticos fue significativamente menor en el grupo 1 (57.3 \pm $20.2 \%$ frente al $97.8 \% \pm 2.5 \%$ a los 10 años, $p=0.025$ ). Los resultados tardíos revelaron un mayor número de complicaciones dependientes del injerto en los pacientes del grupo 1. Dado que los aneurismas inflamatorios tienen más riesgo de desarrollar aneurismas para-anastomóticos, la vigilancia rutinaria mediante pruebas de imagen es obligatoria tras el tratamiento quirúrgico de los AAA inflamatorios.

\section{References}

1. Johnston KW, Rutherford RB, Tilson MD, et al. Suggested standards for reporting on arterial aneurysms. J. Vasc. Surg. 1991;13:452-458
2. Walker DI, Bloor K, Williams G, et al. Inflammatory aneurysms of the abdominal aorta. Br. J. Surg. 1972;59:609-614

3. Rose AG, Dent DM. Inflammatory variant of abdominal atherosclerotic aneurysm. Arch. Pathol. Lab. Med. 1981;105:409-413

4. Schwartz CJ, Mitchell JRA. Cellular infiltration of the human arterial adventitia associated with atheromatous plaques. Circulation 1962;26: 73-78

5. Rasmussen TE, Hallett JW. Inflammatory aortic aneurysms: a clinical review with new perspectives in pathogenesis. Ann. Surg. 1997;225: 155-164

6. Crawford JL, Stowe CL, Safi HJ, et al. Inflammatory aneurysm of the aorta. J. Vasc. Surg. 1985;2:113-124

7. Pennel RC, Hollier LH, Lie JT, et al. Inflammatory abdominal aortic aneurysms: a thirty-year review. J. Vasc. Surg. 1985;2:859-869

8. Goldstone J, Malone JM, Moore WS. Inflammatory aneurysms of the abdominal aorta. Surgery 1978;83:425-430

9. Downs AR, Lye CR. Inflammatory abdominal aortic aneurysm. Can. J. Surg. 1986;29:50-53

10. Lindblad B, Almgren B, Berqvist D, et al. Abdominal aortic aneurysm with perianeurysmal fibrosis: experience from 11 Swedish vascular centers. J. Vasc. Surg. 1991;13:231-239

11. Stella A, Gargiulo M, Faggioli GL, et al. Postoperative course of inflammatory abdominal aortic aneurysms. Ann. Vasc. Surg. 1993;7:229238

12. Von Fritschen U, Malzfeld E, Clasen A, et al. Inflammatory abdominal aortic aneurysm: a postoperative course of retroperitoneal fibrosis. J. Vasc. Surg. 1999;30:1090-1098

13. Bitsch M, Norgaard HH, Roder O, et al. Inflammatory aortic aneurysms: regression of fibrosis after aneurysm surgery. Eur. J. Vasc. Endovasc. Surg. 1997;13:371-374

14. Koch JA, Poll L, Klinger G, et al. Intraoperative findings and postoperative computer tomographic follow up of inflammatory aortic aneurysm. Rofo Fortschr. Geb. Rontgenstr. Neuen. Bildgeb. Verfahr. 1998; 169:140-145

15. Nitecki SS, Hallett JW, Stanson AW, et al. Inflammatory abdominal aortic aneurysms: a case-control study. J. Vasc. Surg. 1996;23:860-869

16. Sasaki S, Yasuda K, Takigami K, et al. Inflammatory abdominal aortic aneurysms and atherosclerotic abdominal aortic aneurysms: comparisons of clinical features and long-term results. Jpn. Circ. J. 1997;61:231235

17. Sterpetti AV, Hunter WJ, Feldhaus RJ, et al. Inflammatory aneurysms of the abdominal aorta: incidence, pathologic, and etiologic considerations. J. Vasc. Surg. 1989;9:643-650

18. McMahon JN, Davies JD, Sott DJA, et al. The microscopic features of inflammatory abdominal aortic aneurysms: discriminant analysis. Histopathology 1990;16:557-564

19. Szilagyi DE, Smith RF, Elliott JP, et al. Anastomotic aneurysms after vascular reconstruction: problems of incidence, etiology, and treatment. Surgery 1975;78:800-816

20. Plate G, Hollier LA, O'Brien P, et al. Recurrent aneurysms and late vascular complications following repair of abdominal aortic aneurysms. Arch. Surg. 1985;120:590-594

21. Dennis JW, Littooy FN, Greisler HP, et al. Anastomotic pseudoaneurysms: a continuing late complication of vascular reconstructive procedures. Arch. Surg. 1986;121:314-317

22. Johnston KW. Canadian Society for Vascular Surgery Aneurysm Study Group. Nonruptured abdominal aortic aneurysm: six-year follow-up results from the multicenter prospective Canadian aneurysm study. J. Vasc. Surg. 1994;20:163-170

23. Edwards JM, Teefey SA, Zierler RE, et al. Intraabdominal paraanastomotic aneurysms after aortic bypass grafting. J. Vasc. Surg. 1992;15: 344-353

24. Hallet JW, Marshall DM, Petterson TM, et al. Graft-related complications after abdominal aortic aneurysm repair: reassurance from a 36year population-based experience. J. Vasc. Surg. 1997;25:277-286

25. Kalman PG, Rappaport DC, Merchant N, et al. The value of late computed tomographic scanning in identification of vascular abnormalities after abdominal aortic aneurysm repair. J. Vasc. Surg. 1999;29:442-450

26. Leseche G, Schaetz A, Arrive L, et al. Diagnosis and management of 17 consecutive patients with inflammatory abdominal aortic aneurysm. Am. J. Surg. 1992;164:39-44

27. Johnston KW, Scobie TK. Multicenter prospective study of nonrup- 
tured abdominal aortic aneurysms. I. Population and operative management. J. Vasc. Surg. 1988;7:69-81

28. Sultan S, Duffy S, Madhavan P, et al. Fifteen-year experience of transperitoneal management of inflammatory abdominal aortic aneurysms. Eur. J. Vasc. Endovasc. Surg. 1999;18:510-514

29. Lacquet JP, Lacroix H, Nevelsteen A, et al. Inflammatory abdominal aortic aneurysms: a retrospective study of 110 cases. Acta Chir. Belg. 1997;97:286-292

30. Cenacchi G, Guiducci G, Pasquinelli G, et al. The morphology of elastin in non-specific and inflammatory abdominal aortic aneurysms: a comparative transmission, scanning and immunoelectron microscopy study. J. Submicrosc. Cytol. Pathol. 1995;27:75-81 